\title{
The Physical, Mechanical, and Sound Absorption Properties of Sandwich Particleboard $(\mathrm{SPb})^{1}$
}

\author{
Apri Heri ISWANTO ${ }^{2, \dagger} \cdot$ Arif Rahman $\mathrm{HAKIM}^{2}$ - Irawati $\mathrm{AZHAR}^{2}$ • \\ Basuki WIRJOSENTONO ${ }^{3} \cdot$ Dita Sari PRABUNINGRUM ${ }^{4}$
}

\begin{abstract}
While the utilization of wood as a raw material in related industries has been increasing with the population increasing, the availability of wood from natural forests has continued to decline. An alternative to this situation is the manufacture of particleboard from non-wood lignocellulose materials through the modification of sandwich particleboard (SPb) using bamboo strands as reinforcement. In this study, strandsof belangke bamboo (Gigantochloa pruriens W) and tali bamboo (Gigantochloa apus) were utilized. The non-wood particles included sugar palm fibers, cornstalk, and sugarcane bagasse. The board was made in a three-layer composition of the face, back, and core in a ratio of 1: 2: 1. The binder used was $8 \%$ isocyanate resin. The sheet was pressed at a temperature of $160^{\circ} \mathrm{C}$ for 5 min under a pressure of $3.0 \mathrm{~N} / \mathrm{mm}^{2}$. Testing included physical and mechanical properties based on the JIS A 5908 (2003) standard, while acoustic testing was based on ISO 11654 (1997) standards. The results showed that using bamboo strands as reinforcement has an effect on the mechanical and physical properties of SPb. Almost all the types of boards met the JIS A 5908 (2003) standards, with the exception of thickness swelling (TS) and internal bond (IB) parameters. Based on the thickness swelling parameter, the C-type board exhibited the best properties. Overall, the B-type board thatused a belangke bamboo strand for the surface and sugarcane bagasse as the core underwent the best treatment. Based on the acoustical parameter, boards using a tali bamboo strand for the surface and sugar palm fiber as the core (E-type board) exhibited good sound absorption properties.
\end{abstract}

Keywords: sandwich particleboard, bamboo, non-wood lignocellulose

\section{INTRODUCTION}

The wood demand as raw material for the timber industry has recently increased. Nevertheless, the availability of wood from natural forests continues to decline to the problematic extent in the timber industry countrywide. Using alternative raw materials in form of non-wood lignocellulose is expected to be a solution to these problems.

Several studies on the utilization of non-wood raw materials in the manufacture of composite boards have been carried out, including the use of sorghum bagasse

\footnotetext{
${ }^{1}$ Date Received March 20, 2019, Date Accepted December 24, 2019

2 Department of Forest Product, Faculty of Forestry, Universitas Sumatera Utara, Padang Bulan, Medan 20155, Indonesia

${ }^{3}$ Department of Chemistry, Faculty of Mathematics and Natural Science, Universitas Sumatera Utara, Padang Bulan, Medan 20155, Indonesia

${ }^{4}$ Batang Gadis National Park, Ministry of Environment and Forestry Republic Indonesia, Mandailing Natal, North Sumatra, Indonesia

† Corresponding author: Apri Heri Iswanto (e-mail: apriheri@yahoo.com, ORCID: 0000-0002-4243-1429)
} 
(Iswanto et al., 2017a; Iswanto et al., 2018a; Iswanto et al., 2018b; Iswanto et al., 2018c; Kusumah et al., 2016), cornstalks (Guler et al., 2015), and bamboo (Maulana et al., 2017; Zhang et al., 2018; Febrianto et al., 2015; Ibrahim and Febrianto, 2013). Based on that, there is a weakness of the particleboard in terms of dimensional stability and strength. Haygreen and Bowyer (1996) explained that the weakness of the particleboard is low dimensional stability. Therefore it had a large effect on usage, especially when used as a building material.

This study showed the effects of using bamboo (Belangke and Tali) and lignocellulose instead of other wood as raw material for sandwich particleboards. In Indonesia, bamboo is potentially utilized as a substitute for wood. It has high flexural and fracture strength. Some studies on the usage of bamboo as a structural composite raw material showed that it has strength almost the same as wood. Febrianto et al. (2015) stated that the strength of oriented strand boards from bamboo reaches 6200 and $51 \mathrm{~N} / \mathrm{mm}^{2}$ for MOE and MOR, respectively.

The Belangke bamboo (Gigantochloa pruriens) is used in this study because it is one of the local species of North Sumatra with significant potential. The distribution of belangke bamboo in the province covers the area in Langkat and Karo districts. Based on its physical properties, this species has to range a specific gravity ranged between 0.60 to $0.70 \mathrm{~g} / \mathrm{cm}^{3}$, so is suitable to be used as a raw material for composite boards. Through a combination of bamboo as a surface layer and non-lignocellulosic materials such as bagasse, cornstalks, and sugar palm fiber as a core layer was expected to recover the weakness of particleboard, especially in terms of strength. The purpose of this study was to analyze the physical, mechanical, and acoustical properties of sandwich particleboard from belangke bamboo, tali bamboo, and other lignocellulosic materials.

\section{MATERIALS and METHODS}

\subsection{Materials}

Materials used in this research included belangke bamboo (Gigantochloa pruriens), tali bamboo (Gigantochloa Apus), cornstalk, sugarcane bagasse, and Sugar palm fiber. The description particles were shown in Table 1.

Table 1. Non-wood lignocellulose (NWL) materials

\begin{tabular}{|c|c|c|c|c|}
\hline No & $\begin{array}{l}\text { NWL } \\
\text { type }\end{array}$ & Size & Figure & $\begin{array}{l}\text { Position } \\
\text { in } \\
\text { Layer }\end{array}$ \\
\hline 1 & $\begin{array}{l}\text { Bamboo } \\
\text { strand }\end{array}$ & $\begin{array}{l}25 \mathrm{~cm} \\
\text { (length) } \\
\text { by } 2.5 \mathrm{~cm} \\
\text { (width) by } \\
0.1 \mathrm{~cm} \\
\text { (thickness) }\end{array}$ & & $\begin{array}{l}\text { Surface } \\
\text { layer }\end{array}$ \\
\hline 2 & $\begin{array}{l}\text { Sugar } \\
\text { palm } \\
\text { fiber }\end{array}$ & $\begin{array}{l}2.5 \mathrm{~cm} \\
\text { (length), } \\
0.2 \mathrm{~mm} \\
\text { (diameter) }\end{array}$ & & $\begin{array}{l}\text { Core } \\
\text { layer }\end{array}$ \\
\hline 3 & Cornstalk & $\begin{array}{l}5 \text { cm } \\
\text { (length) }\end{array}$ & & $\begin{array}{l}\text { Core } \\
\text { layer }\end{array}$ \\
\hline 4 & $\begin{array}{l}\text { Sugarcane } \\
\text { bagasse }\end{array}$ & $\begin{array}{l}5 \text { cm } \\
\text { (length) }\end{array}$ & & $\begin{array}{l}\text { Core } \\
\text { layer }\end{array}$ \\
\hline 5 & $\begin{array}{l}\text { Bamboo } \\
\text { particle }\end{array}$ & $\begin{array}{l}5 \mathrm{~cm} \\
\text { (length) } \\
\text { by } 0.1 \mathrm{~cm} \\
\text { (width) by } \\
0.1 \mathrm{~cm} \\
\text { (thickness) }\end{array}$ & & $\begin{array}{l}\text { Core } \\
\text { layer }\end{array}$ \\
\hline
\end{tabular}




\subsection{Type of sandwich particleboard}

Sandwich particleboard were of 8 types including of A (Belangke bamboo / Sugar palm fiber / Belangke bamboo), B (Belangke bamboo / Sugarcane bagasse / Belangke bamboo), C (Belangke bamboo / Cornstalk / Belangke bamboo), D (Belangke Bambo / Mixed bamboo / Belangke bamboo), E (Tali bamboo / Sugar palm fiber / Tali bamboo), F (Tali bamboo / Sugarcane Bagasse / Tali bamboo), G (Tali bamboo / Cornstalk / Tali bamboo), and $\mathbf{H}$ (Tali bamboo / Mixed Bamboo / Tali bamboo). Models of sandwich particleboard were as shown in Fig. 1.

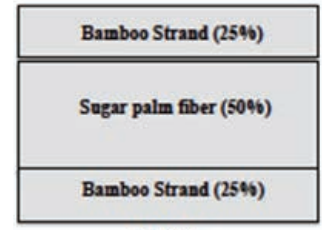

Model 1

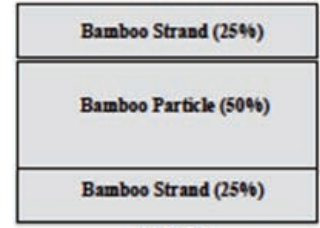

Model 3

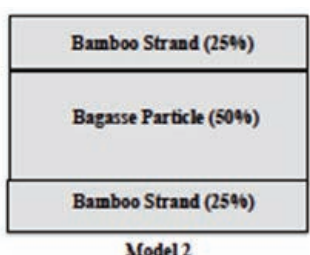

Model 2

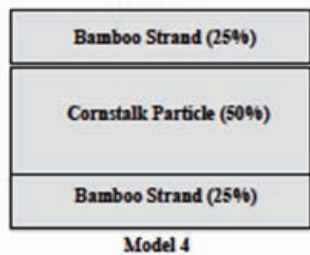

Fig. 1. Models of sandwich particleboard.

\subsection{Board manufacturing}

Sandwich particleboard was produced in size of 25 by $25 \mathrm{~cm}^{2}$ with density and thickness target of 0.75 $\mathrm{g} / \mathrm{cm}^{3}$ and $10 \mathrm{~mm}$, respectively. The particles were mixed with isocyanate resin at an $8 \%$ level. Furthermore, in the mat-forming process, bamboo was placed as a surface layer and another lignocellulose as a core layer with a composition ratio of 1:2:1 (Fig. 1). Hotpress machine was set based on temperature, time, and pressure of $160^{\circ} \mathrm{C}$ and $5 \mathrm{~min}$ and pressure of $3 \mathrm{~N} / \mathrm{mm}^{2}$ respectively. Before the test, boards were conditioned for 14 days in room temperature conditions.

\subsection{Board evaluation}

\subsubsection{Physical and mechanical test}

The sample of tests made conformed to JIS A 5908 (2003) standard. Furthermore, board testing was also carried out with the parameters of particleboardtesting consisting of density, moisture content (MC), water absorption (WA), thickness swelling (TS), internal bond (IB), modulus of elasticity (MOE), and modulus of rupture (MOR). The testing of the physical and mechanical properties of particleboard was JIS A 5908 standard (2003).

\subsubsection{Acoustical test}

The sample was prepared in the form of a circle with a $3 \mathrm{~cm}$ diameter according to JIS A 1405 (1963). The sound absorption coefficient was determined in the test. The sample was placed in an impedance tube (Fig. 2). The sound absorption coefficient was calculatedby measuring sound pressure on the material surface along with the reflected.

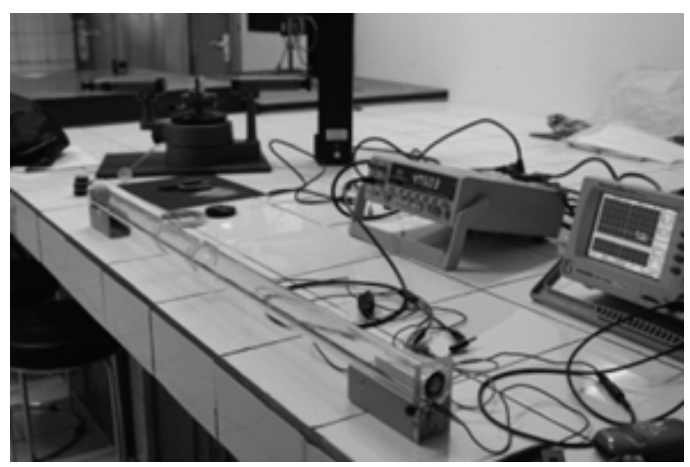

Fig. 2. Acoustical equipment.

\section{RESULTS and DISCUSSION}

\subsection{Physical properties}

\subsubsection{Density and moisture content}

Based on Fig. 3, it could be seen that the density 


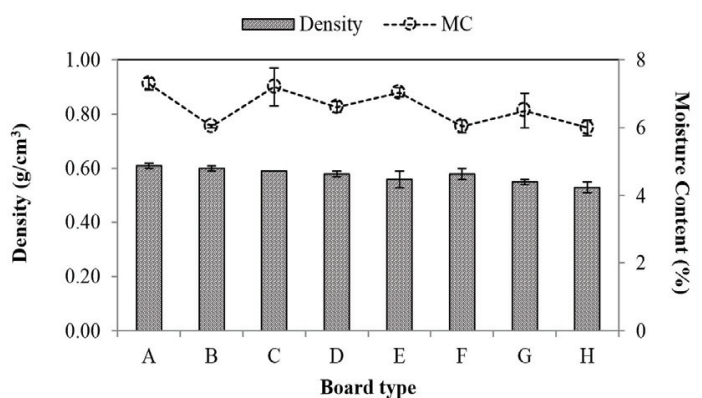

Fig. 3. Density and moisture content of sandwich particleboard.

value of $\mathrm{SPb}$ made from belangke bamboo for surface ranged between of 0.58 to $0.61 \mathrm{~g} / \mathrm{cm}^{3}$, this value is higher than that of tali bamboo that ranged between of 0.53 to $0.58 \mathrm{~g} / \mathrm{cm}^{3}$. It was due to the specific gravity of belangke bamboo which higher than tali bamboo. According to Kelly (1977), one of the factors influencing board density value is raw material density. The specific gravity of belangke bamboo and tali ranged between 0.60 to 0.70 and 0.40 to 0.50 respectively. The density of sandwich particleboardhad not reached the target density of $0.75 \mathrm{~g} / \mathrm{cm}^{3}$. It was due to board thickness more than the thickness target after the conditioning process (spring back effect). Springback value in this study was $25 \%$. Similar conditions were shown in the research conducted by Iswanto et al. (2017b) on threelayer particleboard boards made fromwood shavings and bonded with a mixture of UF and UMF. Overall board density values in this research met JIS A 5908 (2003) that requires a density value of 0.40 to 0.90 $\mathrm{g} / \mathrm{cm}^{3}$ (JSA, 2003).

The moisture content of $\mathrm{SPb}$ ranged between 6.00 to $7.29 \%$ (Fig. 3), with the lowest value on the H-type board and the highest on the A-type board. The use of Sugar palm fiberas a core layer produced a high-level moisture content of the board. This is caused by bonding strength between the Sugar palm fiberand isocyanate adhesive is low as indicated by the low value of the internal bond of the board. Overall, the moisture content of SPb produced met JIS A 5908 standard (2003) which is 5 to $13 \%$.

\subsubsection{Thickness Swelling (TS) and Water Absorption (WA)}

Fig. 4 shows the value of TS ranged from 8.29 to $22.94 \%$. The use of sugar palm fibers and bamboo particles as the core layer produced a relatively high TS value. Two things lead to the low moisture content of sugar palm fiber, specifically less than $5 \%$, which affected the optimization of the isocyanate gluing process. Sugar palm fiberhad a character similar to hydrophobic material. A sufficient amount of water was needed by an isocyanate adhesive to produce a good bonding reaction. Furthermore, the cause of the high TS value on the board with bamboo particles as the core layer was the presence of starch content. Moreover, the high extraction of bamboo prevented the penetration of the adhesive. For this reason, the bond betweenthe particles and the adhesive was low, covered by the results of a low internal bond for $\mathrm{SPb}$ with core fibers and bamboo particles. The trend in Fig 4 shows that $\mathrm{TS}$ of $\mathrm{SPb}$ with belangke bamboo as a surface was not significantly different in value compared to boards with tali bamboo. Thickness swelling were determine by the type of constituent particles in the core layer. Subiyanto et al. (2008) stated that one of the factors affecting TSvalues is the type of particle. Based on JIS A 5908 (2003) the TS value of SPb that meets

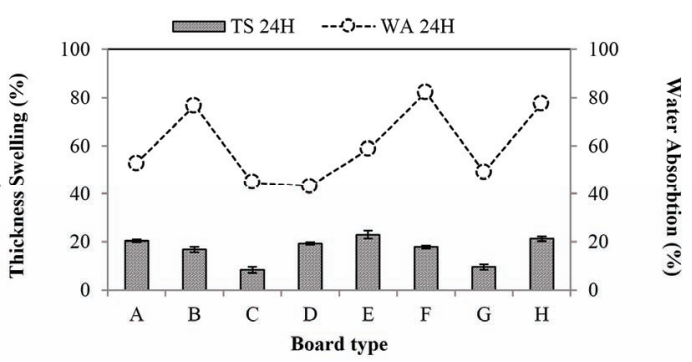

Fig. 4. The thickness swelling and water absorption of sandwich particleboard. 
ofthe standard was only C-type and G-type of boards with a value of $8.29 \%$ and $9.56 \%$ respectively.

The highest WA value was found on the board with bagasse particles. This was due to the presence of cavities formed on particleboards as a result of the roughness of adhesive and sugarcane bagasse used which contained the pith (cork). Lengel (1999) stated that pith is a water-absorbing material and its weight can increase to seven times after the absorption from its original mass. Overall, $\mathrm{SPb}$ that used ofbelangke bamboo had a lower WA value than tali bamboo as a surface layer. This was because belangke bamboo density was higher than that of the tali bamboo. Vital et al. (1974) stated that the particleboarddensity value is inversely proportional to the value of WA. Also, Buffalino et al. (2012) also stated that water absorption was influenced by board density and different adhesive content.

\subsection{Mechanical properties}

\subsubsection{Modulus of Elasticity (MOE) and Modulus of Rupture (MOR)}

The MOE values ranged from 2,404.00 to $4,303.13$ $\mathrm{N} / \mathrm{mm}^{2}$ (Fig 5). Belangke bamboo strandboards as surface layers have a higher MOE value compared to the tali bamboo strandbecause the specific gravity of belangke bamboo is higher than tali bamboo. Rofii et al. (2013) stated that the usage of materials with a high density in the face layer obtains a better curvature compared to low specific gravity materials. Norvydas and Minelga (2006) reported that MOE is related to the type, structure, and thickness of the coating material. Furthermore, Iswanto et al. (2017) stated that bamboo strands have higher flexural strength compared to plywood. Overall, the MOE value of sandwich particleboard applying tali bamboo and belangke bamboo as coatings met the JIS 5908 (2003) standard.

The MOR value ranged from 14.94 to $43.15 \mathrm{~N} / \mathrm{mm}^{2}$

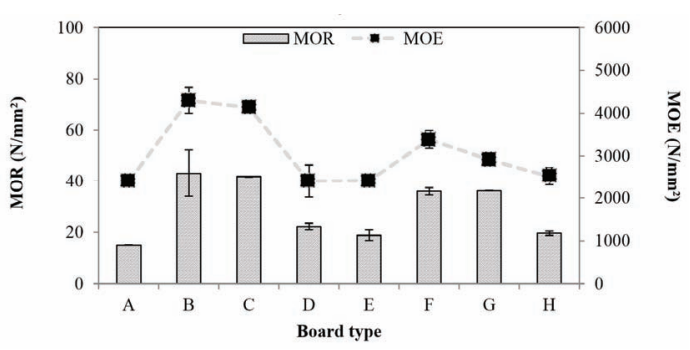

Fig. 5. Modulus of elasticity and modulus of rupture sandwich particleboard.

(Fig. 5). According to Fig 5, it can be seen that the board with belangke bamboo as the surface layer had a higher MoR value than the tali bamboo. The effect of specific gravitydifferences is attributed to the occurrence of this condition. Hwang et al. (2006) stated that the adhesive content and specific gravity types have an important influence on the MOR value. Overall, the MOR value of $\mathrm{SPb}$ using tali bambooand belangke bamboo met the JIS 5908 (2003) standard.

\subsubsection{Internal Bond (IB)}

Internal bond values ranged from 0.03 to $0.40 \mathrm{~N} / \mathrm{mm}^{2}$ (Fig. 6).

The board using sugar palm fibers in the core had the lowest IB value. This was due to the non-absorbent nature of the fibers. It would be difficult to create a bond between good adhesive and particles. Furthermore, the hydrophobic nature of the fibers caused the MDI adhesive difficulties in reacting chemically, and therefore the hydroxyl groups in MDI adhesive chemical

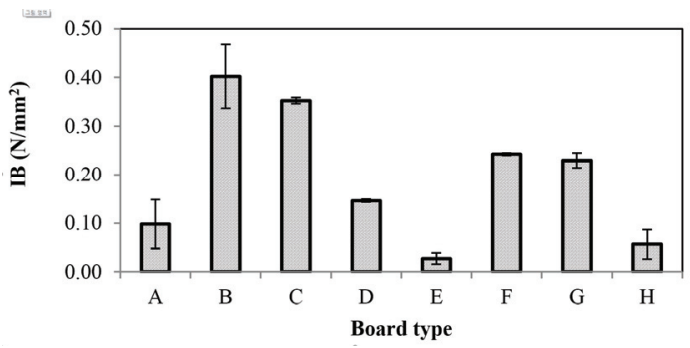

Fig. 6. Internal bond of sandwich particleboard. 
The Physical, Mechanical, and Sound Absorption Properties of Sandwich Particleboard (SPb)

Table 2. Sound absorption coefficient values of sandwich particleboard.

\begin{tabular}{|c|c|c|c|c|c|c|c|c|}
\hline \multirow{2}{*}{ Frequency (Hz) } & \multicolumn{8}{|c|}{ Board type } \\
\hline & A & $\mathrm{B}$ & $\mathrm{C}$ & $\mathrm{D}$ & $\mathrm{E}$ & $\mathrm{F}$ & $\mathrm{G}$ & $\mathrm{H}$ \\
\hline & \multicolumn{8}{|c|}{ Absorption coefficient } \\
\hline 250 & 0.7 & 0.6 & 0.7 & 0.9 & 0.8 & 0.8 & 0.7 & 0.8 \\
\hline 750 & 0.5 & 0.6 & 0.6 & 0.5 & 0.5 & 0.5 & 0.6 & 0.5 \\
\hline 1250 & 0.5 & 0.4 & 0.4 & 0.5 & 0.4 & 0.3 & 0.4 & 0.3 \\
\hline 1750 & 0.4 & 0.5 & 0.4 & 0.5 & 0.5 & 0.5 & 0.4 & 0.5 \\
\hline 2250 & 0.4 & 0.7 & 0.6 & 0.6 & 0.6 & 0.6 & 0.7 & 0.6 \\
\hline 2750 & 0.6 & 0.5 & 0.4 & 0.5 & 0.6 & 0.3 & 0.4 & 0.4 \\
\hline 3250 & 0.7 & 0.4 & 0.6 & 0.9 & 0.8 & 0.6 & 0.5 & 0.8 \\
\hline 3750 & 0.8 & 0.2 & 0.3 & 0.9 & 0.9 & 0.4 & 0.3 & 0.8 \\
\hline 4250 & 0.7 & 0.3 & 0.4 & 0.8 & 0.9 & 0.4 & 0.5 & 0.7 \\
\hline 4750 & 0.6 & 0.3 & 0.4 & 0.6 & 0.9 & 0.7 & 0.6 & 0.5 \\
\hline 5250 & 0.5 & 0.3 & 0.6 & 0.7 & 0.9 & 0.7 & 0.6 & 0.7 \\
\hline Average values & 0.6 & 0.4 & 0.5 & 0.7 & 0.7 & 0.5 & 0.5 & 0.6 \\
\hline
\end{tabular}

reactions are necessary. MDI in the isocyanate group $(-\mathrm{N}=\mathrm{C}=\mathrm{O})$ reacts with hydroxyl groups in wood to form urethane chains (Marra, 1992). The use of bamboo as a coating material does not increase the IB value. Sari et al. (2013) stated that surface coating applications do not improve IB values. It was due to IB is the bond strength between particles at the core layer.

\subsection{Acoustical properties}

The sound absorption ability of each board was dissimilar due to the influence of composition from the structure board material itself (the constituents of each board). The more porous a material is, the greater its ability to absorb sound. The sound absorption coefficient on $\mathrm{SPb}$ was as shown in the following Table 2.

Based on Table 2, the E-type of board samples had the absorption coefficient valuesat the highest frequency which was equal to 0.9 at the frequency of $5250 \mathrm{~Hz}$. Oktavia and Elvaswer (2014) stated that the porous material absorbs sound better at high frequencies because the sound wavelength will be shorter. Therefore the sound circulatedin the tube had a high sound wave pressure than the sample. Thus, more sound waves need to be absorbed by the sample than the reflected one. The smallest absorption coefficient was in B-type of board sampleswith 0.2 at a frequency of $3750 \mathrm{~Hz}$. Oktavia and Elvaswer (2014) stated that at low frequencies, sound waves that circulate in a tube have a long wavelength $(\lambda)$ therefore the reflected waves are greater than waves absorbed by the material.

Different sound absorption responses are also affected by the thickness of the board itself. The thicker of the material resulted in a higher absorption coefficient. It was due toa thick material that had a lot of porous space and fiber, and therefore good as a noise-reducing material. The thickness data for each sample was presented in Table 3.

The quality of sound-absorbing material is indicated by the value of the absorption coefficient. From the result of research, all test sampleshave more than 0.15 sound absorption coefficients. According to ISO 11654 (1997), it can be included in the category of sound 
Table 3. The thickness data of each sample

\begin{tabular}{cc}
\hline Sample & Thick $(\mathrm{cm})$ \\
\hline \hline A & 1.22 \\
B & 1.27 \\
C & 1.32 \\
D & 1.36 \\
E & 1.26 \\
F & 1.26 \\
G & 1.24 \\
H & 1.30 \\
\hline
\end{tabular}

absorbent material. Doelle (1986) stated that the characteristics of porous absorbent materials efficiently absorb sound at high frequencies compared to low frequencies. The more porous an acoustic material is, the greater the absorption of sound. Hayat et al. (2013) stated that the greater of board density value resulted in the lower sound absorption coefficient value, and vice versa.

\section{CONCLUSION}

The use of cornstalks as core layer produced the best dimensional stabilization of the board. This was shown by the low value of the thickness swelling produced. Moreover, the use of blanket bamboo as a surface layer offered better board strength compared to tali bamboo. For the overall acoustic properties parameter, the resulting board meets ISO 11654 (1997) standards with the best value found on board made from a combination of tali bamboo for surface and Sugar palm fiber as the core. All types of boards produced belong to the category of sound absorbent material where the coefficient of sound absorption produced more than 0.15 .

\section{ACKNOWLEDGMENT}

We would like to express my sincere thanks to the University of Sumatera Utara for supporting research funds through to "Talenta Research Grant” No: 5388/ UN5.1.R/PPM/2017 Date of May 22, 2017.

\section{REFERENCES}

Bufalino, L., Albino, V.C.S., VA, de Sá., Corrêa, A.A.R., Mendes, L.M., Almeida, N.A. 2012. Particleboards Made from Australian Red Cedar: Processing Variables and Evaluation of MixedSpecies. Journal Tropical Forest Science 24(2): 162-172.

Doelle, L.L. 1986. Akustik Lingkungan. Erlangga. Jakarta, Indonesia.

Febrianto, F., Jang, J.H., Lee, S.H., Santosa, I.A., Hidayat, W., Kwon, J.H., Kim, N.H. 2015. Effect of Bamboo Species and Resin Content on Properties of Oriented Strand Board Prepared from Steamtreated Bamboo Strands. Bioresources 10(2): 26422655.

Guler, C., Copur, Y., Tascioglu, C. 2008. The Manufacture of Particleboards Using Mixture of Peanut Hull (Arachis hypoqaea L.) and European Black Pine (Pinus nigra Arnold) Wood Chips. Journal of Bioresource Technology 99(8): 2893- 2897.

Hayat, W., Syakbaniah, Darvina, Y. 2013. Pengaruh Kerapatan Terhadap Koefisien Absorbsi Bunyi Papan Partikel Serat Daun Nenas (Ananas comosus L merr). Pillar of Physics 1(1): 44-51.

Hwang, G.S., Wang, E.I.C., Su, Y.C. 2006. Preparation of composite board using foil-laminated and plastic-laminated liquid packaging paperboard as raw materials. Journal of Wood Science 52(3): 230-235.

Ibrahim, M.A., Febrianto, F. 2013. Properties of Oriented Strand Board (OSB) Made from Mixing Bamboo. ARPN Journal of Science and Technology 3(9): 937-962.

ISO 11654. 1997. Acoustical Sound Absorbers for Use in Buildings-Rating of Sound Absorption. 
Iswanto, A.H., Aritonang, W. Azhar, I., Fatriasari, W. 2017a. The Physical, Mechanical and Durability Properties of Sorghum Bagasse Particleboard by Layering Surface Treatment. Journal of the Indian Academy of Wood Science 14(1): 1-8.

Iswanto, A.H., Simarmata, J., Fatriasari, W., Azhar, I., Sucipto, T., Hartono R. 2017b. Physical and Mechanical Properties of Three-layer Particleboards Bonded With UF and UMF Adhesives. Journal of the Korean Wood Science and Technology 45(6): 787-796.

Iswanto, A.H., Febrianto, F., Hadi, Y.S., Ruhendi, S., Hermawan, D., Fatriasari, W. 2018a. Effect of Particle Pre-Treatment on Properties of Jatropha Fruit Hulls Particleboard. Journal of the Korean Wood Science and Technology 46(2): 155-165.

Iswanto, A.H., Supriyanto, Fatriasari, W., Susilowati, A. 2018b. Effect of particle treatment and adhesive type on physical, mechanical, and durability properties of particleboard made from Sorghum Bagasse. Friendly City 4 Conference. IOP Conf. Series: Earth and Environmental Science 126 (2018): 012016 doi:10.1088/1755-1315/126/1/012016.

Iswanto, A.H., Febrianto, F., Hadi, Y.S., Ruhendi, S., Hermawan, D. 2018c. Jatropha fruit hulls (JFH) particleboard: Effect of acetic acid treatment and ratio of JFH and non-wood particles. Friendly City 4 Conference. IOP Conf. Series: Earth and Environmental Science 126 (2018): 012015 doi: 10.1088/1755-1315/126/1/012015.

Japanese Standard Association. 2003. Japanesse Industrial Standard Particle Board JIS A 5908. Tokyo.

Kelly, M.W. 1977. Critical Literature Review of Relationship Between Processing Parameter and Physical Properties of Particleboard. General Technical Report FPL-10. Wisconsin: Department of Agriculture Forest.

Kusumah, S.S., Umemura, K., Yoshioka, K., Miyafuji, H., Kanayama, K. 2016. Utilization of sweet sorghum bagasse and citric acid for manufacturing of particleboard I: Effects of pre-drying treatment and citric acid content on the board properties. Industrial Crops and Products 84: 34-42.

Lengel, D.E. 1999. AG-fibers: They look like fibers - they act like fibers. Why not make fiberboards?. Proceedings of the Meeting of the Eastern Canadian Section of the Forest Products Society. May 19-20, Winnipeg, Manitoba.

Marra, A.A. 1992. Technology of Wood Bonding Principles in Practise. New York (USA): Van Nostrand Reinhold Pr.

Maulana, S., Busyra, I., Fatrawana, A., Hidayat, W., Sari, R.K., Sumardi, I., Wistara, I.N.J., Lee, S.H., Kim, N.H., Febrianto, F. 2017. Effects of Steam Treatment on Physical and Mechanical Properties of Bamboo Oriented Strand Board. Journal of the Korean Wood Science and Technology 45(6): 872-882.

Norvydas, V., Minelga, D. 2006. Strength and Stiffness Properties of Furniture Panels Covered with Different Coatings. Materials Science 12(4): 328332.

Oktavia, A., Elvaswer. 2014. Pengaruh jumlah celah permukaan bahan kayu lapis (Plywood) terhadap koefisien absorbsi bunyi dan impedansi akustik. Jurnal Fisika Unand 3(3): 135-139.

Rofii, M.N., Yumigeta, S., Suzuki, S., Prayitno, T.A. 2013. Effects of Shelling Ratio and Particle Characteristic on Physical Properties of ThreeLayered Particleboard Made From Different Wood Species. Wood Research Journal 4(1): 25-30.

Sari, B., Nemli G, Mehmet B, Bardak S, Emir Z. 2013. The Role of Solid Content of Adhesive and Panel Density on The Dimensional Stability and Mechanical Properties of Particleboard. Journal of Composite Materials 47(10): 1247-1255.

Subiyanto, B., Rasyid, E., Gopar, M., Firmanti, A. 2008. Veneer and Thin Plywood Overlaid for 
Apri Heri ISWANTO • Arif Rahman HAKIM - Irawati AZHAR • Basuki WIRJOSENTONO • Dita Sari PRABUNINGRUM

Quality Improvement of Particleboard Made of Palm Oil Empty Fruit Bunches (EFB). Journal of Tropical Wood Science and Technology 6(1): 17-20.

Vital, B.R., Lehmann, W.F., Boone, R.S. 1974. How Species and Board Density Affect Properties of Exotic Hardwood Particleboard. Forest Product
Journal 24(12): 37-45.

Zhang, Y.H., Huang, Y.X., Ma, H.X., Yu, W.J., Qi, Y. 2018. Effect of Different Pressing Processes and Density on Dimensional Stability and Mechanical Properties of Bamboo Fiber-based Composites. Journal of the Korean Wood Science and Technology 46(4): 355-361. 